\title{
Growth and yields parameters of cassava crop (Manihot esculenta Crantz) as affected by plant density, genotype and planting system ${ }^{1}$
}

\author{
Angela María Burgos ${ }^{2 *}\left(\mathbb{1}\right.$, Ricardo Daniel Medina ${ }^{2,3}$, Elisa Noemí Fukuda ${ }^{2}$, Ramón Jesús Hidalgo ${ }^{2,4}$
}

10.1590/0034-737X202168060006

\begin{abstract}
In Argentina, cassava (Manihot esculenta) production does not meet the national demand. The aim of this work was to analyze the effects of two planting systems of the stem cuttings (horizontal and vertical), two plant densities $\left(10,000\right.$ and 20,000 plant ha $\left.{ }^{-1}\right)$ and two cassava genotypes ( $c v$. Palomita and Blanca de Santa Catarina) on biometric variables and on root and starch yields by means of a field experiment carried out in Corrientes, Argentina. Eight treatments were distributed following a randomized complete block design. The following variables were evaluated: cutting sprouting percentage, plant height, percentage of intercepted photosynthetically active radiation (PARi); total, shoot and root fresh weight per hectare and/or per plant; starch production per hectare and weed dry biomass. Blanca de Santa Catarina (BSC) demonstrated the best yield potential. Vertical planting determined higher sprouting percentages, plant length and PARi, consequently greater conversion into biomass and starch. Higher plant density was associated with lower weed dry biomass and with lower root yield per plant. In conclusion, in cassava producing areas, such as Corrientes, which has sandy soils, the vertical planting system at a density of 10,000 plant ha ${ }^{-1}$ with the $c v$. BSC could be recommended to increase cassava yield without additional costs.
\end{abstract}

Keywords: cuttings; planting; production; tuberous roots; starch.

\section{INTRODUCTION}

Cassava (Manihot esculenta Crantz, Euphorbiaceae), one of the three major tuberous crops produced worldwide, is also a main material for starch and alcohol production (Balagopalan et al., 2002). Actually just $14 \%$ of cassava is produce in America (Howeler, 2014). Argentina is the southernmost cassava producing country in the word representing just about $0.76 \%$ of total South American output with 194,452 tonnes annually grown in 19,417 hectares of the northeast region (FAOSTAT, 2020).

Argentine cassava root production is not enough to satisfy its domestic starch demand, where the idle capacity of cassava industries actually exceeds 50\% (Aristizábal $\&$ Calle, 2015). In this context, cassava starch represented $32 \%$ of the total starches imported during the period 2000-
2019, which highlights the importance for the national industry (CAFAGDA, 2020).

Improve cassava productivity with a better crop management and without any additional cost, should include the most effective options such as to choose the appropriate genotype, the suitable plant density and an optimal weed control methodology (Howeler, 2014).

Particularly in cassava crop, the optimal density to reach maximum yield, will depend on the growth habit of the genotypes (Ospina \& Ceballos, 2002). This will determine the most suitable plant density in order to use the environmental resources efficiently.

Although cassava is a rustic crop, one of the factors that can affect its cultivation efficiency is crop weed competition (Ospina \& Ceballos, 2002; Howeler, 2014).

\footnotetext{
Submitted on October $10^{\text {th }}, 2020$ and accepted on February $18^{\text {th }}, 2021$.

${ }^{1}$ This work was part of the graduation thesis of Fukuda, Elisa Noemí to access the title of Agricultural Engineer from the National University of the Northeast (UNNE), Corrientes, Argentina. This research was financed by Secretaría General de Ciencia y Técnica of Universidad Nacional del Nordeste (UNNE).

${ }^{2}$ Facultad de Ciencias Agrarias, Universidad Nacional del Nordeste, Departamento de Producción Vegetal, Corrientes, Argentina. burgosangela@agr.unne.edu.ar; sumi_fukuda@hotmail.com ${ }^{3}$ Instituto de Botánica del Nordeste, Universidad Nacional del Nordeste - Consejo Nacional de Investigaciones Científicas y Técnicas, Corrientes, Argentina. ricardomedina@agr.unne.edu.ar; ricardo74ar@yahoo.com.ar

${ }^{4}$ Facultad de Ingeniería, Universidad Nacional del Nordeste, Resistencia, Argentina. rj_hidalgo@yahoo.com.ar

*Corresponding author: burgosangela @agr.unne.edu.ar
} 
During the critical period, first 90 days after plantation (dap), crop weed competition can lead to reductions of up to $90 \%$ in root yield, representing $30 \%$ or more of production costs (Silva et al., 2012). In Argentina, weed control is usually done through manual or mechanical removal. None agrochemical has yet been registered to be used in cassava crop in the country.

Cassava cuttings can be planted in different positions and vertical planting system is recommended principally because it favors highest sprouting percentage and early initial growth (Aristizábal \& Sánchez, 2007). For these reasons, this system should be considered as a cultural weed control method since there is still no herbicide allowed for this crop in Argentina.

The objective of this work was to evaluate sustainable production systems based on ecophysiological studies that would contribute to explain the generation of cassava yield of two genotypes planted in two densities and with two cutting planting systems in a subtropical and sandy soil growing region.

\section{MATERIALS AND METHODS}

The study was carried out in the Experimental Field of the Facultad de Ciencias Agrarias, Universidad Nacional del Nordeste (UNNE) in November from 2013 to May 2014. This place is located in Corrientes province ( $27^{\circ} 28^{\prime}$ Lat. S and $58^{\circ} 16^{\prime}$ Long. W), Argentina. The climate is humid mesothermal Cf w'a (h), considering the modified Köppen Climate Classification System, and it is characterized by average annual rainfall of $1,300 \mathrm{~mm}$ and average annual temperature of $21.6^{\circ} \mathrm{C}$ (Murphy, 2008).

The soil is classified as Argic Udipsamment, mixed, hyperthermic, it is moderately to slightly acidic on the horizon A; and it has a sandy texture, low fertility and low cation-exchange capacity (Escobar et al., 1994). Soil samples taken from the field at $0-0.20 \mathrm{~m}$ depth showed the following chemical properties, $\mathrm{pH}=5.51$, Organic matter $=$ 0.64 , Phosphorus $=11.32 \mathrm{mg} \mathrm{dm}^{-3}$, Calcium $=1.19 \mathrm{cmolc}$ $\mathrm{kg}^{-1}$, Magnesium $=0.40 \mathrm{cmolc} \mathrm{kg}^{-1}$ and Potassium $=0.11$ cmolc kg-1.

Two cassava contrasting genotypes widely disseminated in Argentina were selected to carry out this study. Both genotypes are locally denominated as cultivar Palomita and Blanca de Santa Catarina (BSC), respectively. The $c v$. Palomita is a late branching genotype and it has leaves with linear lobes. On the other hand, the $c v$. BSC is an early branching genotype and it has leaves with lanceolate lobes. Furthermore, $c v$. BSC has a larger canopy size respect to $c v$. Palomita in association with their growth habits.

Eight treatments were established in order to study the effects of two planting systems of the stem cuttings (horizontal or vertically positioned), two plant densities
$(10,000$ and 20,000 plant ha-1 $)$ and two cassava genotypes ( $c v$. Palomita and $c v$. BSC). The densities were determined by planting patterns of $1 \times 1 \mathrm{~m}$ and $1 \times 0.5 \mathrm{~m}$. The experimental was a randomized complete block design with three replications, 24 plants per treatment were sampled, corresponding 8 plants per replication. The plots of each replication had $15 \mathrm{~m}^{2}, 4$ rows of $5 \mathrm{~m}$ length each one spaced by $1 \mathrm{~m}$ between rows. Only the central rows were used for taking samples, while the other rows were considered borders.

The soil was prepared in a conventional way by two crosswise passes of a disc plough and a light harrow. The planting was carried out during the first week of November 2013 with neither supplementary water irrigation nor nutrient supplied. Stem cuttings were cut with a length of $10 \mathrm{~cm}$ and $20 \mathrm{~cm}$ for the horizontal and vertical planting system, respectively. The stem cuttings were completed covered by the soil at approximately $8 \mathrm{~cm}$ deep when they were horizontally planted, while with the vertical system the cuttings were buried up to $50 \%$ of their length.

Several variables were measured: cutting sprouting $(\%)$ : the observation of the first expanded leaf 10, 17 and 24 dap was taken as reference; plant height $(\mathrm{cm})$ : plants were measured randomly by repetition 30,60 and 90 dap; intercepted photosynthetically active radiation (PARi): it was recorded with a ceptometer (portable and linear PAR sensor, Cavadevices, Buenos Aires, Argentina); and measured between the soil and the first green leaf 90 and 150 dap; it was expressed as a percentage in relation to the global incident radiation. After the manual harvest (210 dap), each plant was cut and weighed separately in shoot and root fractions. Thus, it was obtained root fresh weight per plant $\left(\mathrm{g} \mathrm{plant}^{-1}\right)$ and other biometrical variables such as shoot fresh weight per hectare $\left(\mathrm{t} \mathrm{ha}^{-1}\right)$ and root fresh weight per hectare $\left(\mathrm{t} \mathrm{ha}^{-1}\right)$ were estimated. Adding shoot and root fractions of each plant, total fresh weight per hectare $\left(\mathrm{t} \mathrm{ha}^{-1}\right)$ was calculated for each plant density. Starch production per hectare ( $\mathrm{t} \mathrm{ha}^{1}$ ) was calculated considering root starch concentration determined by the gravimetric method (Toro \& Cañas, 1983). In order to obtain weed dry biomass $\left(\mathrm{g} \mathrm{m}^{-2}\right)$ a random sampling was done on each repetition 75 dap, using a frame $\left(1 \mathrm{~m}^{2}\right)$ where weeds were removed using a hoe, and then they were dried in an oven at $70^{\circ} \mathrm{C}$ until constant weight was achieved.

For all variables, data was submitted to variance analysis (ANOVA) and Duncan's Multiple Range Test (P $\leq 0.05$ ), checking a prior normality test by InfoStat software version 2008 (Di Rienzo et al., 2016). To perform the ANOVA, data that did not have a Gaussian distribution were transformed by $\log _{10}(x+2)$, such as PARi, root fresh weight and starch production per hectare, and weed dry biomass. 


\section{RESULTS}

\section{Cutting sprouting}

Simple factors evaluated such as genotype $(\mathrm{G})(\mathrm{P}<$ $0.0001)$, planting system (PS) $(\mathrm{P}<0.0001)$, plant density (PD) $(\mathrm{P}=0.0161)$ and their two-way interactions produced a significant effect on cassava cutting sprouting. Also the interaction $\mathrm{G} v s$. PS vs. PD showed significant differences in the cutting sprouting percentage (Figure 1a; $\mathrm{P}=0.0040$ ). In both plant densities, the $c v$. BSC proved to be sensitive to the planting system showing a significant increase in the cutting sprouting percentage when it was vertically positioned, but not the $c v$. Palomita $(\mathrm{P}<0.0001)$. When the interaction PS $v s$. PD was analyzed, it was also observed that the vertical position significantly increased the cutting sprouting percentage regardless of the plant density $(\mathrm{P}=$ $0.0040)$. The highest percentage (83\%) was obtained in $c v$. $\mathrm{BSC}$ when it was planted at the lower density $(\mathrm{P}=0.0040)$.

\section{Plant height}

Plant height was found to be very sensitive to all factors studied (genotype, $\mathrm{P}=0.0246$; planting system, $\mathrm{P}$ $<0.0001$; plant density, $\mathrm{P}=0.0001)$ and its three-way interaction $(\mathrm{P}<0.0001)$. Respect to the genotype effect, $c v$. BSC significantly surpassed the $c v$. Palomita in terms of plant height. The analysis of the G vs. PS interaction revealed a prominent influence of the vertical position on the plant height in both genotypes $(\mathrm{P}=0.0307)$, which in general were $81 \%$ taller than those obtained with the horizontal system. This pronounced effect of the vertical planting system on plant height was also observed when the three-way interaction was tested (Figure 1b; P < 0.0001 ). If only the plant density is considered, the plants were about $14 \%$ taller with 10,000 plant $\mathrm{ha}^{-1}$ than with 20,000 plant ha ${ }^{-1}(\mathrm{P}=0.0001)$.

\section{Intercepted photosynthetically active radiation}

The percentage of intercepted photosynthetically active radiation (PARi) by the crop varied considerably with the genotype $(\mathrm{P}<0.0001)$ and was affected by the planting system $(\mathrm{P}<0.0001)$. After 90 dap, the PARi ranged from $20 \%-58 \%$ in $c v$. Palomita and from $40 \%-80 \%$ in $c v$. BSC. Evidently, $c v$. Palomita intercepted a lower percentage of the incoming PARi than $c v$. BSC, on average $40 \%$ and $60 \%$, respectively. Moreover 150 dap, this average increased to $55 \%$ in $c v$. Palomita, while $c v$. BSC reached $78 \%$. The highest PARi reached by $c v$. BSC $(\mathrm{P}<0.0001)$ may be associated with its early branching habit. On the other hand, the vertical planting system allowed increasing the PARi in both genotypes evaluated and plant densities (Figure 1c; $\mathrm{P}=0.0498$ ). The higher PARi with the vertical plantation and with the lowest plant density may be associated to the greater height of the plants favored by both factors (Figure 1b).

\section{Total fresh weight per hectare}

The total fresh weight (TFW) expressed as biomass in tonnes per hectare showed a significant response with regard to the genotype $(\mathrm{P}<0.0001)$ and the planting system $(\mathrm{P}<0.001)$. The greater TFW was reached by the $c v$. BSC and with the vertical planting system in comparison with the $c v$. Palomita and the horizontal planting system, respectively. The two-way interaction $\mathrm{PS} v s$. $\mathrm{PD}(\mathrm{P}=0.022)$; and the three-way interaction $\mathrm{G} v s$. PS vs. PD ( $\mathrm{P}=0.0003)$ were also analyzed. From this analysis, it became clear that the vertical planting system favors higher biomass generation, regardless of plant density (Figure 2a). This response would be associated to the highest PARi observed with the vertical planting system (Figure 1c).

\section{Shoot fresh weight per hectare}

The shoot fresh weight (SFW) represents the aerial biomass of the crop, composed of the stems and leaves of the canopy. The SFW in tonnes per hectare was significantly modified by the genotype $(\mathrm{P}<0.0001)$, planting system $(\mathrm{P}<0.0001), \mathrm{G} v s$. PS $(\mathrm{P}<0.0001), \mathrm{G} v s$. PD ( $\mathrm{P}=0.014), \mathrm{PS} v s . \mathrm{PD}(\mathrm{P}=0.007)$ and $\mathrm{G} v s$. PS vs. $\mathrm{PD}$ (Figure $2 \mathrm{~b} ; \mathrm{P}<0.0001)$. Thus, plant density alone does not determine the final SFW, but rather determines it in combination with each genotype and the planting system, or both factors. In this way, both genotypes produced more SFW when vertically planted at the same plant density. The $G$ $v s$. PD interaction determined that the $c v$. BSC produces greater SFW regardless of the plant density. This finding is probably associated with the early branching growth habit of the $c v$. BSC.

\section{Root fresh weight per plant}

The root fresh weight per plant (RFW) showed significant differences in terms of genotype $(\mathrm{P}<0.0001)$, planting system $(\mathrm{P}<0.0001)$, plant density $(\mathrm{P}<0.0001)$, the interactions $\mathrm{G} v s$. $\mathrm{PD}(\mathrm{P}=0.0007)$ and $\mathrm{G} v$ s. PS vs. PD (Figure 3a; $\mathrm{P}=0.0454)$. When the three-way interaction was analyzed, it was evident that the vertical planting system had a positive effect on the RFW per plant in both genotypes (Figure 3a). Besides, the use of the highest plant density had a detrimental effect on RFW per plant (Figure 3a).

\section{Root fresh weight per hectare}

The partition of the biomass towards the roots determines the crop yield $\left(\mathrm{t} \mathrm{ha}^{-1}\right)$. This variable was significantly affected by genotype $(\mathrm{P}<0.0001)$, by planting system $(\mathrm{P}$ $<0.0001)$, and also by the G vs. PS vs. PD interaction $(\mathrm{P}=0.0309)$. The $c v$. BSC yielded about $80 \%$ more RFW per hectare than $c v$. Palomita, and on the other hand, the vertical planting system promoted an increase in yield of $120 \%$ in relation to the horizontal planting system, regardless of 
plant density (Figure 3b). When comparing the RFW per plant (Figure 3a) and the RFW per hectare (Figure 3b), a compensation effect related to plant density was observed, thus with low density the greater individual yield achieves to compensate for the lower number of plants per hectare. The most widespread plant density in this cassava production area, which is 10,000 plant $\mathrm{ha}^{-1}$, turned out to be the optimum for both genotypes to express their individual root yield potential that compensates for the lower number of plants.

\section{Starch production per hectare}

The starch production per hectare responded significantly to the genotype $(\mathrm{P}<0.0001)$ and to the planting system $(\mathrm{P}<0.0001)$ as much as the interaction $\mathrm{G}$ vs. $\mathrm{PS} v s$. $\mathrm{PD}(\mathrm{P}=0.0496)$. The starch production of $c v$. BSC was $81 \%$ higher than that of $c v$ Palomita $(\mathrm{P}<0.0001)$, this is consistent with the results observed in RFW per hectare (Figure 3b). The same compensative effect observed in RFW per hectare due to the plant density was found in starch production per hectare (Figure 3c).

(1)
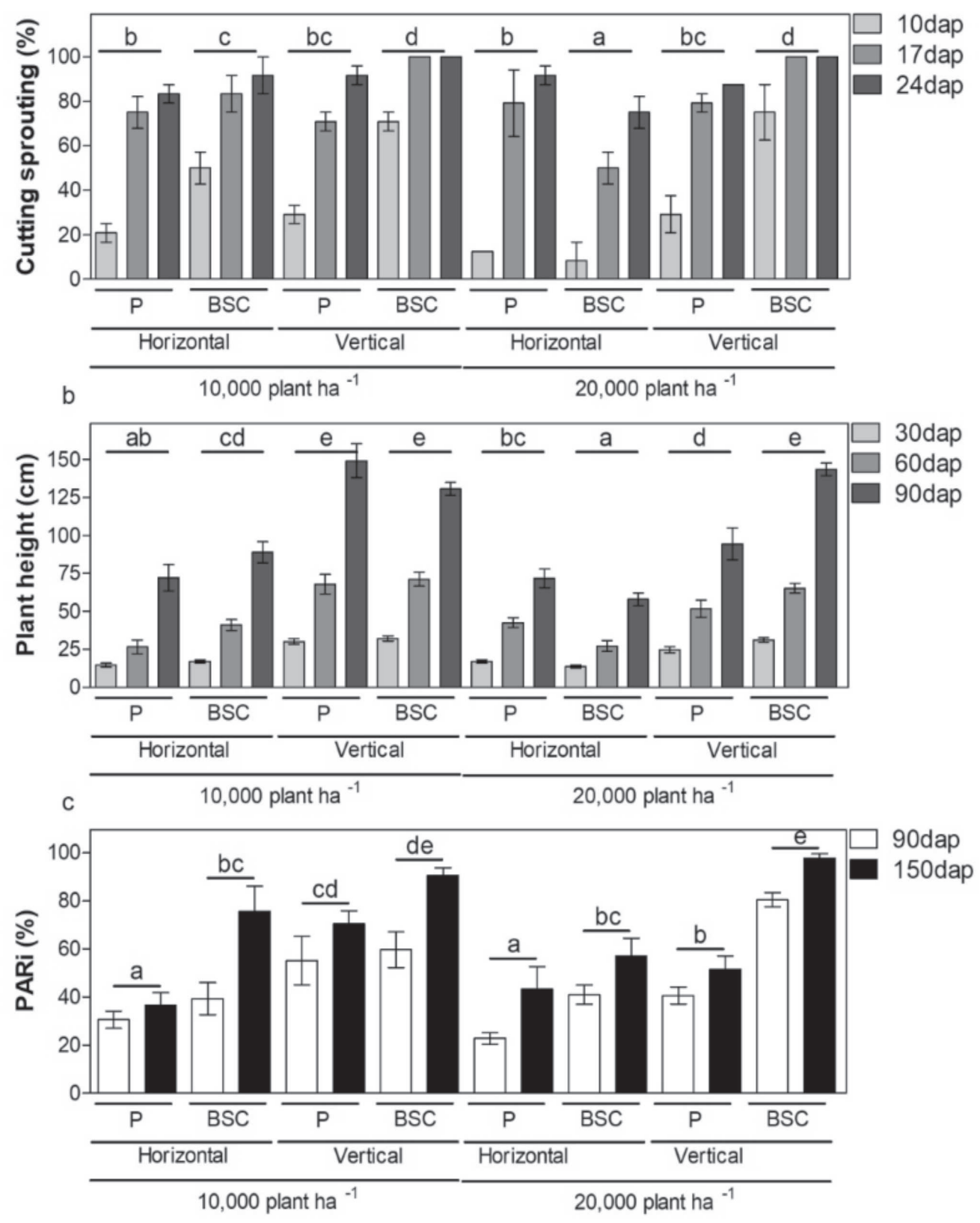

Figure 1: a) Dynamics of cassava cutting sprouting (\%), b) plant height $(\mathrm{cm})$ and c) percentage of intercepted photosynthetically active radiation (PARi, \%) by two cassava genotypes ( $c v$. Palomita and $c v$. Blanca de Santa Catarina) with two plant densities (10,000 and 20,000 plant ha $\left.^{-1}\right)$ and two planting systems (horizontal and vertical), measured at different days after planting (dap). Different letters indicate major differences due to genotype $v s$. planting system $v s$. plant density interaction, according to Duncan's Multiple Range Test $(\mathrm{P} \leq 0.05)$. 
Regardless of the plant density, the $c v$. Palomita showed an increase in starch production per hectare related to vertical planting system (Figure 3c). However, the $c v$. BSC showed differences in starch production related to the vertical planting system only with 20,000 plant ha-1 (Figure 3c). When analyzing particularly the incidence of the planting system, it was observed that vertical planting led to an increase in starch production per hectare of $121 \%$ compared to horizontal planting ( $\mathrm{P}<$ 0.0001).

\section{Weed dry biomass}

Weeds are considered the main component of the agroecosystem which reduces the cassava crop productivity, taking this into account, it was observed how the experimental design influenced weed control during the critical period. The statistical analysis of our experiment demonstrated that only the variable plant density affected weed dry biomass (Table $1 ; \mathrm{P}=0.011$ ). In consequence, the higher the plant density $\left(20,000\right.$ plant ha $\left.{ }^{-1}\right)$, the lower the weed dry biomass and the greater the weed control.

\section{DISCUSSION}

Since the final crop yield is the result of growth rates and the underlying ecophysiological changes (Boote et al., 2001), it is expected to be influenced by the genotype used. In this research, significant differences due to genotype were recorded and its effect was early detected after planting. In this sense, $c v$. BSC presented a higher cutting sprouting percentage compared with $c v$. Palomita in the measurements made the first 24 dap. While Velásquez (2006) found no differences among eight cultivars studied, in coincidence with our research Lozano et al. (1983) pointed out that genetic variability establishes considerable differences regarding the sprouting, rooting and plant vigor. Moreover, the plants of the $c v$. BSC were significantly taller than those from $c v$. Palomita, showing their vigorous habit. Alves (2002) attributed the variations in plant height to the genotype, as well as to growth conditions and cultural practices.

Since cassava productivity is determined by its biomass production rate and its efficiency in photosynthate accumulation in tuberous roots, anything that contributes to improve the photosynthetic process is of great importance for yield generation (Ramanujan, 1990). In relation to this, in our experiment it was observed that the vertical planting system significantly increased the cutting sprouting percentage regardless of plant density. These results coincided with Anikwe \& Ikenganyia (2018) and with Aristizábal \& Sánchez (2007) who reported that the vertical planting is recommended because it promotes a higher sprouting percentage. These authors also reported an early initial growth when cuttings were planted vertically. Likewise, these plants were $81 \%$ taller than those derived from horizontal planting in the first 90 dap. Furthermore, these plants had intercepted $58 \%$ more PAR

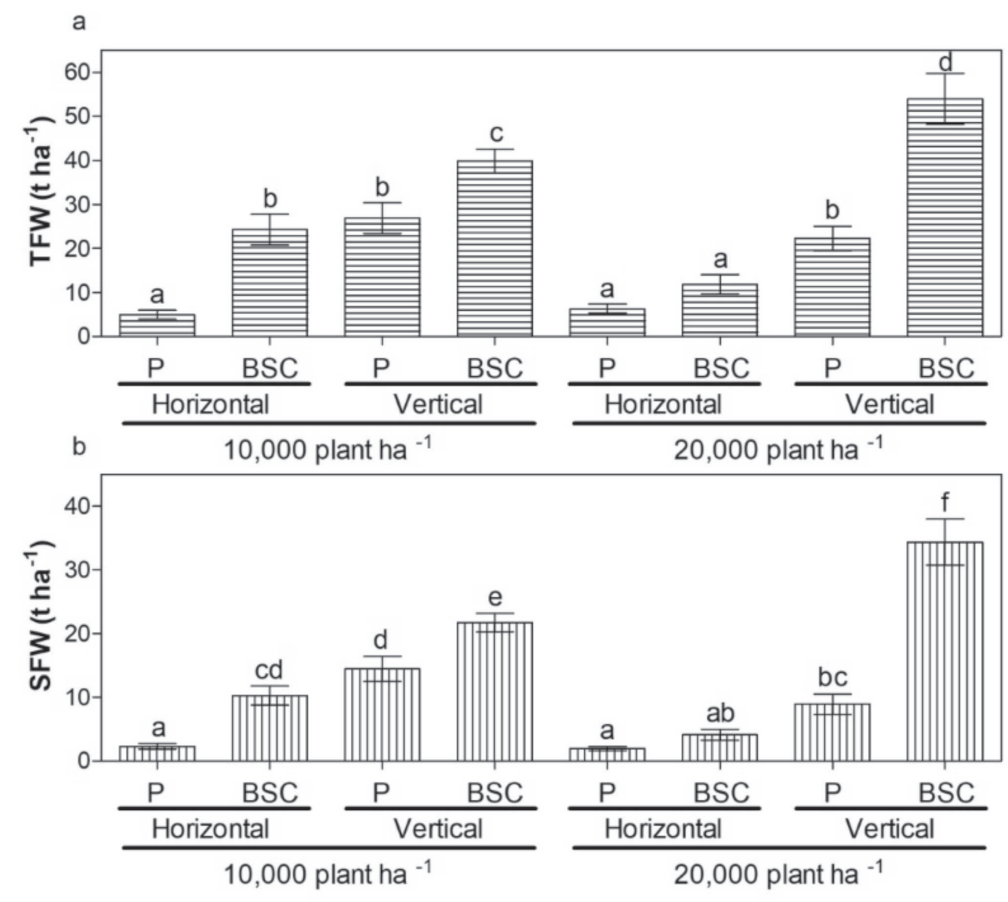

Figure 2: a) Total (TFW) and b) shoot fresh weight (SFW) per hectare $\left(\mathrm{t} \mathrm{ha}^{-1}\right)$ of two cassava genotypes ( $c v$. Palomita and $c v$. Blanca de Santa Catarina) with two plant densities (10,000 and 20,000 plant ha ${ }^{-1}$ ) and two planting systems (horizontal and vertical), measured 210 days after planting (dap). Different letters indicate major differences due to genotype $v s$. planting system $v s$. plant density, according to Duncan's Multiple Range Test $(\mathrm{P} \leq 0.05)$. 
between 90 and 150 dap, which was associated with higher biomass conversion and higher starch accumulation.

Veltkamp (1985) reported a close relationship between the yield and the PARi, but the last variable was significantly modified by the management. Thus, the adequate genotype played an important role in yield increase, but other crop management practice was almost equally important, particularly the planting system as our experiment showed.

Vertical plantation was a determinant management factor in improving yields. The vertical planting system allowed increasing the PARi per cassava crop in both genotypes and at both plant densities. This point is of particular importance, since Veltkamp (1985) found a linear relationship between total dry matter yield and PARi. The same author, studding particularly four cultivars, found that about $50 \%$ of PARi was reached at 60 to 90 dap; two of them reached $90 \%$ of PARi 125 dap, while all of the cultivars intercepted $90 \%$ of PARi just at 152 dap. In our experiment, the fraction of incoming PARi during the first 150 dap, about $60 \%$ of an annual crop cycle, was $90 \%$ for $c v$. BSC when planted vertically. On the other hand, $c v$. Palomita did not even intercept $60 \%$ at its best yield when planted vertically.

It became clear that total fresh biomass generation, as well as shoot and root fresh biomass were significantly higher due to the effect of vertical planting system, regardless of plant density. This could be explained by the higher PARi when cuttings were vertically planted. Particularly associated with its early branching habit, $c v$. BSC produces greater shoot fresh weight per hectare than $c v$. Palomita. On the other hand, $c v$. BSC also yielded about
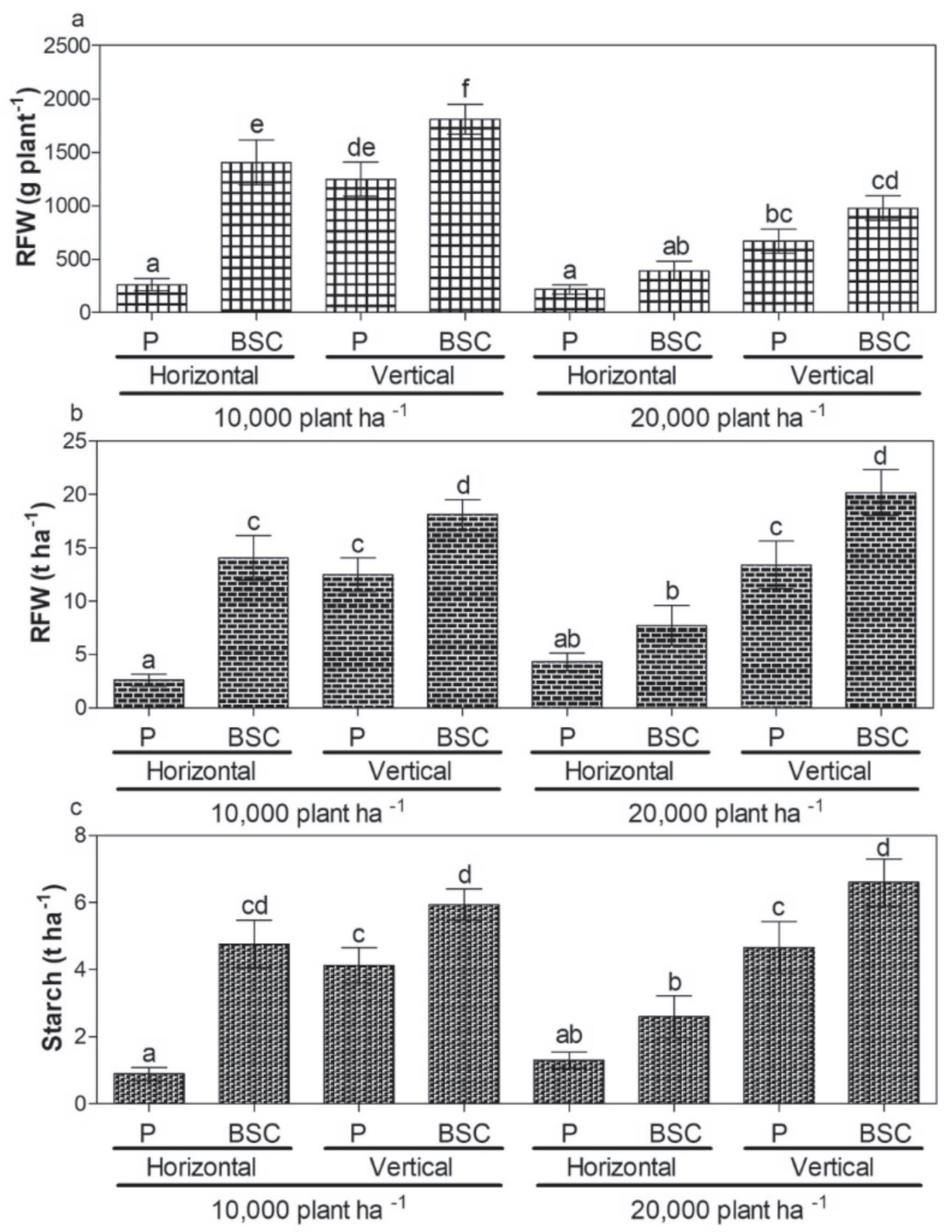

Figure 3: a) Root fresh weight (RFW) per plant $\left.\left(g_{\text { plant }}^{-1}\right), b\right)$ root fresh weight $(R F W)$ per hectare $\left(t^{-1} a^{-1}\right)$ and $\left.c\right)$ starch production per hectare $\left(\mathrm{t} \mathrm{ha}^{-1}\right)$ of two cassava genotypes ( $c v$. Palomita and $c v$. Blanca de Santa Catarina) with two plant densities (10,000 and

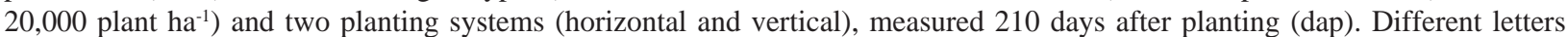
indicate major differences due to genotype $v s$. planting system $v s$. plant density interaction, according to Duncan's Multiple Range Test $(\mathrm{P} \leq 0.05)$. 
$80 \%$ more root fresh weight per hectare than $c v$. Palomita, regardless of the plant density used. In fact, Palomita and BSC showed significant yield differences. At this point it is questionable whether the branching pattern itself caused the root yield increase or whether it is in association with the vertical planting system.

In general, as vertical planting had a significant positive effect on root yield, it also improved the starch production per hectare in both genotypes. In contrast, the use of a high plant density had a detrimental effect on the yield per plant. Our results differ from reports by Aristizábal \& Sanchez (2007) in which the planting position had no influence on yield. Nevertheless, they agree with studies carried out by Howeler (2014) in Asia, Legese et al. (2011) in Africa and Conceição (1983) and Ospina \& Ceballos (2002) in South America, who found that vertical or angled planting produced significantly higher root yield than horizontal planting. According to Legese et al. (2011), cuttings horizontally planted sprout slower and at a significantly lower rate than vertically or angled planted cuttings.

In relation to the plant density, Howeler (2014) reported that increasing the plant density the yield of each plant would decrease due to the competition from neighboring plants as it affects the efficiency of light and space use. López (2002) also points out a decrease in root size due to an increase in plant density. In our experiment with no nutrient supplied sandy soil, 10.000 plant $\mathrm{ha}^{-1}$ was the optimum density to achieve the maximum yield per hectare for both genotypes, thus compensating for the lower plant stand. As for root production per hectare a compensatory effect due to plant density on starch yield per hectare was also observed.

Cassava is a poor competitor and can suffer serious yield losses if the crop is not properly weeded during the early stages of plant growth. In our research, plant density was the only factor that considerably affected weed dry biomass, in agreement with Peressin (2013) who considers

Table 1: Weeds dry biomass (WDB) $\left(\mathrm{g} \mathrm{m}^{-2}\right)$ accumulated in the first 75 days after planting (dap) in two cassava genotypes ( $c v$. Palomita and $c v$. Blanca de Santa Catarina) with two plant densities (10,000 and 20,000 plant ha $\left.{ }^{-1}\right)$ and two planting systems (horizontal and vertical)

\begin{tabular}{|c|c|c|c|c|}
\hline Cultivar & Planting system & $\begin{array}{l}\text { Plant density } \\
\left(\text { plant } \text { ha }^{-1}\right)\end{array}$ & $\begin{array}{l}\text { WDB } \\
\left(\mathrm{g} \mathrm{m}^{-2}\right)\end{array}$ & p-value \\
\hline Palomita & - & - & $46.3 *$ & \multirow{2}{*}{0.4370} \\
\hline Blanca de Santa Catarina & - & - & 44.5 & \\
\hline- & Horizontal & - & 50.8 & \multirow{2}{*}{0.1897} \\
\hline- & Vertical & - & 39.9 & \\
\hline- & - & 10,000 & $61.0 \mathrm{a}^{* *}$ & \multirow{2}{*}{0.0011} \\
\hline- & - & 20,000 & $29.8 \mathrm{~b}$ & \\
\hline \multirow{2}{*}{ Palomita } & Horizontal & - & 50.4 & \multirow{4}{*}{0.5352} \\
\hline & Vertical & - & 42.2 & \\
\hline \multirow{2}{*}{ Blanca de Santa Catarina } & Horizontal & - & 51.3 & \\
\hline & Vertical & - & 37.8 & \\
\hline & - & 10,000 & 58.5 & \multirow{4}{*}{0.2026} \\
\hline Palomita & - & 20,000 & 34.1 & \\
\hline \multirow{2}{*}{ Blanca de Santa Catarina } & - & 10,000 & 63.6 & \\
\hline & - & 20,000 & 25.4 & \\
\hline- & & 10,000 & 66.0 & \multirow{4}{*}{0.4370} \\
\hline- & Horızontal & 20,000 & 35.7 & \\
\hline- & \multirow{2}{*}{ Vertical } & 10,000 & 56.1 & \\
\hline- & & 20,000 & 23.8 & \\
\hline Palomita & Horizontal & 10,000 & 63.5 & \multirow{8}{*}{0.5886} \\
\hline Blanca de Santa Catarina & Horizontal & 10,000 & 68.5 & \\
\hline Palomita & Vertical & 10,000 & 53.5 & \\
\hline Blanca de Santa Catarina & Vertical & 10,000 & 58.7 & \\
\hline Palomita & Horizontal & 20,000 & 37.3 & \\
\hline Blanca de Santa Catarina & Horizontal & 20,000 & 34.0 & \\
\hline Palomita & Vertical & 20,000 & 30.8 & \\
\hline Blanca de Santa Catarina & Vertical & 20,000 & 16.8 & \\
\hline
\end{tabular}

* Mean value of the Weed dry biomass (WDB). **Different letters indicate statistical differences due to plant density according to Duncan's Multiple Range Test $(\mathrm{P} \leq 0.05)$. 
it as a key cultural factor for this purpose. High plant density favors the early canopy closure reducing weed presence. Consequently, this factor should be taken into account as a cultural control in an integrated weed management program (Howeler, 2014).

On the other hand, as mentioned above, higher density caused a detrimental effect on cassava yield per plant, so it is not considered as a suitable crop management practice. Anikwe \& Ikenganyia (2018) mentioned that weeds can also be controlled in cassava using the cultural method, for example, the use of increased plant population. Even so, an integrated weed management can be employed. This involves the use of a combination of methods to achieve desired results, e.g., use of a preemergence herbicide which is followed by subsequent hand weeding.

Finally, since cultural practices are not enough to reduce weed competition, it is imperative to promote the herbicide experimentation for cassava in Argentina.

\section{CONCLUSION}

Genotype variations were associated with differences in biomass and its subsequent partition, interacting with all other productivity factors, thus $c v$. BSC showed its initial sprouting vigor and maximum final yield potential. The vertical planting system of the cassava stem cuttings optimized the expression of the ecophysiological components that determine roots and starch yields. The optimum plant density was 10.000 plant ha ${ }^{-1}$, which compensated the lower number of plants per hectare with the highest yield per plant.

Based on the results of this study, cassava producing areas such as Corrientes which has sandy soils, the vertical planting system at a density of 10,000 plant ha ${ }^{-1}$ with the $c v$. BSC could be recommended to increase cassava yield without additional costs.

The findings obtained in this study show that the potential yield of cassava can be improved by changing the traditional horizontal planting system for a vertical planting system in this production area.

\section{ACKNOWLEDGMENTS, FINANCIAL SUPPORT AND FULL DISCLOSURE}

We would like to show our gratitude to the Secretaría General de Ciencia y Técnica, Universidad Nacional del Nordeste (UNNE) for providing financial support for the research projects PI 18A001, PI 18A007 and D 006/17.

The authors declare that there is no conflict of interest.

\section{REFERENCES}

Alves AAC (2002) Cassava Botany and Physiology. In: Hillocks RJ, Tresh JM \& Belloti AC (Eds.) Cassava: Biology, Production and Utilization. New York, CABI Publishing. p.67-89.
Anikwe MAN \& Ikenganyia EE (2018) Ecophysiology and production principles of cassava (Manihot species) in Southeastern Nigeria. In: Waisundara VY (Ed.) Cassava. Sidney, Australian College of Business \& Technology. p.105122.

Aristizábal J \& Sánchez T (2007) Guía técnica para producción y análisis de almidón de yuca. Roma, Food and Agriculture Organization of the United Nations. 134p. (Technical Bulletin, $163)$.

Aristizábal J \& Calle F (2015) Producción, procesamiento, usos y comercialización de mandioca. Buenos Aires, Instituto Nacional de Tecnología Industrial. 78p. (Technical Bulletin, 22).

Balagopalan C, Hillocks RJ \& Thresh JM (2002) Cassava utilization in food, feed and industry. In: Hillocks RJ, Tresh JM \& Belloti AC (Eds.) Cassava: Biology, Production and Utilization. New York, CABI Publishing. p.301-318.

Boote KJ, Kropff MJ \& Bindraban PS (2001) Physiology and modelling of traits in crop plants: implications for genetic improvement. Agricultural Systems, 70:395-420.

CAFAGDA - Cámara Argentina de Fabricantes de Almidones, Glucosas, Derivados y Afines (2020) Importaciones. Almidones. apertura por tipo de materia prima. Available at: http://cafagda.com.ar/estad_impo.htm. Accessed on: August $14^{\text {th }}, 2020$.

Conceição AJ (1983) A mandioca. Cruz das Almas, Nobel. 383p.

Di Rienzo JA, Casanoves F, Balzarini MG, Gonzalez L, Tablada M \& Robledo CW (2016) InfoStat version 2008. Córdoba, Grupo InfoStat/Universidad Nacional de Córdoba. 336p.

Escobar H, Ligier D, Melgar R, Matteio H \& Vallejos O (1994) Mapa de Suelo de la Provincia de Corrientes 1:500.000. Corrientes, Instituto Nacional de Tecnología Agropecuaria. $125 \mathrm{p}$.

FAOSTAT - Statistics division of Food and Agriculture Organization of the United Nations (2019) FAOSTAT Statistics division: Crops. Available at: http://www.fao.org/faostat/en/\#data/QC. Accessed on: August 14 ${ }^{\text {th }}, 2020$.

Howeler R (2014) Sustainable Soil and Crop Management of Cassava in Asia. Cali, Centro Internacional de Agricultura Tropical. 280 p.

Legese H, Gobez L, Shegro A \& Geleta N (2011) Impact of planting position and planting material on root yield of cassava (Manihot esculenta Crantz). Journal of Agricultural Science and Technology, 5:448-454.

López J (2002) Semilla vegetativa de yuca. In: Ospina B \& Ceballos $\mathrm{H}$ (Eds.) La yuca en el Tercer Milenio. Sistemas modernos de producción, procesamiento, utilización y comercialización. Cali, Centro Internacional de Agricultura Tropical. p.49-75.

Lozano JC, Toro JC, Castro A \& Bellotti AC (1983) Selección y preparación de estacas de yuca para la siembra. In: Domínguez CE (Ed.) Yuca: Investigación, producción y utilización. Cali, Programa de las Naciones Unidas para el Desarrollo, Centro Internacional de Agricultura Tropical. p.209- 229.

Murphy GM (2008) Atlas Agroclimático de la Argentina. Buenos Aires, Universidad de Buenos Aires. 130p.

Ospina B \& Ceballos H (2002) La yuca en el Tercer Milenio. Sistemas modernos de producción, procesamiento, utilización y comercialización. Cali, Centro Internacional de Agricultura Tropical. 586p.

Peressin VA (2013) Manejo integrado de plantas danhinas na cultura da mandioca. San Pablo, Instituto Agronômico de Campinas. 54 p.

Rev. Ceres, Viçosa, v. 68, n.6, p. 546-554, nov/dec, 2021 
Ramanujan T (1990) Effect of moisture stress on photosynthesis and productivity of cassava. In: Ospina B \& Ceballos H (Eds.) La yuca en el Tercer Milenio. Sistemas modernos de producción, procesamiento, utilización y comercialización. Cali, Centro Internacional de Agricultura Tropical. p.34-45.

Silva DV, Santos JB, Carvalho FP, Ferreira EA, França AC, Fernandes JSC, Gandini EMM \& Cunha VC (2012) Seletividade de herbicidas pós-emergentes na cultura da mandioca. Planta Daninha, 30:835-841.
Toro JC \& Cañas A (1983) Determinación del contenido de materia seca y almidón en yuca por el sistema de gravedad específica. In: Domínguez CE (Ed.) Yuca: investigación, producción y utilización. Cali, Programa de las Naciones Unidas para el Desarrollo, Centro Internacional de Agricultura Tropical. p.567575

Velásquez EJ (2006) Efecto de la variabilidad en genotipos de yuca sobre factores vinculados a la brotación y crecimiento de esquejes. Bioagro, 18: 41-48.

Veltkamp HJ (1985) Physiological causes of yield variation in cassava (Manihot esculenta Crantz). Wageningen Agricultural University. 103p. 